\title{
Focus on environmental assessment needs for water resources development projects in India
}

\author{
L. S. Deshpande \& P. S. Kelkar \\ Geo-Environment Management Division, \\ National Environmental Engineering Research Institute, India
}

\begin{abstract}
This paper presents a situation analysis of water resource development projects in India and the need for environmental assessment of such projects. The finite water resources will not be adequate unless measures such as rainwater harvesting and inter-basin water transfers are implemented. An approach for the sustainable development of such projects must be adopted through proper environmental assessment. Apart from technical/scientific interventions it is necessary to create awareness to utilize water resources optimally. The mitigation measures must be interwoven while preparing the project document. The benefits accrued must take into consideration the damages posed to the environment. The paper presents details about the impact of river action plans carried out in India. The paper also emphasises the need for an appropriate environmental impact study with a holistic approach towards water resources development.

Keywords: environmental assessment, water resources development, sustainable development, rainwater harvesting, inter-basin transfer.
\end{abstract}

\section{Introduction}

Water is the elixir of life. India is blessed with a bounty of fresh water. The Himalayas, the Vindhyas, the Eastern and Western Ghats intercept the monsoon rainfall and thus the rivers flow in abundance during a short period of rainfall. The distribution of rainfall, however, is such that India, perhaps, is a unique country facing both flood and draught concurrently. The floods are experienced in some parts and at the same time some other part is anxiously waiting for rains, 
which are so crucial for rain fed agriculture. Civilizations after civilization have lived in India utilizing the advantage of rain in such a manner that floods are controlled and draughts are mitigated.

\section{Historical note}

Development of network for utilizing the river water has been known even in Indian antiquities. The story of Aruni controlling the floods in agriculture land of his Guru, depicted in epic Mahabharata, refers to the use of rainwater for irrigation. The isolated attempts based on the efforts of kings and the leaders of rural community are recorded in the history. These pertain to impounding rainwater for use at later period for irrigation. The remains of rainwater harvest structure at Kadiri, district Ananthapur, Andhra Pradesh signifies the efforts and success of the technology. It may be mentioned here that the township of Kadiri is in the rain shadow area of Rayalaseema and was the place of summer military camp for the army of the King Krishnadevaraya. The rainwater harvest structure and practice were neglected over the period and the township of Kadiri now face the problem of excessive fluoride in ground water used for domestic consumption. Kadiri has a defluoridation plant of 2.27 million liters per day and is the largest defluoridation plant in the world (Defluoridation, Technology Package, NEERI, [2]). The township of Kadiri thus has pioneered modern defluoridation technology and also witnessed the ruined rainwater harvest structure. The Western and Eastern Yamuna canals, which continue to irrigate the adjoining land, were initiated during the period of the king Shahajahan.

The work of significance, contributing to establishment of modern irrigation engineering, was carried out in $19^{\text {th }}$ century in India. The predominant ones were the canal system of Punjab, Madras Presidency, Karnataka and Orissa. The Beas Sutlej Link (BSL) Project with diversion of about 4716 million cubic meter of Beas water into Sutlej falling through the elevation difference of 320 meters is the largest tunneling project in the country (Andey and Nanoti, [2]). The powerhouse at Dehar at the tail end of the system has an installed capacity of 990 MW. The project supplies power to the Northern Grid as well as water to the arid areas in the south and southwest of erstwhile state of Punjab. These structures served as models for engineering practices in river terrain, inter-basin transfer and formation of barrages, and providing gates for release of flood water and execution of canal systems.

\section{Water resources of India}

Sustainable management of water resources system for all present and future demands includes irrigated agriculture, industrial demand, urban and rural water supply, hydropower etc. The water requirement and anticipated demand in India for the year 2050 is presented in Table 1. Water resources available have multiple demands, which are of competing as well as conflicting nature. The land and water resources scenario of India is presented in Table 2. These water resources have spatial and temporal variation to large extent and the allocation 
are carried out through various physical infrastructure such as reservoir, canals, pumping and pipelines. The estimated utilizable surface water potential and net utilizable ground water sources for irrigation are 1132 cubic $\mathrm{km}$ as against the projected demand of 1450 cubic $\mathrm{km}$ (wrmin.nic.in/resource/cwresourc.1.htm) Water sources planning need realistic assessment of resources demand supply pattern and effective operation of infrastructure. The water management involves complex consideration for the physical infrastructure, which has considerable effect or water availability and socio-economic system, which influence the water use.

Table 1: The water demand projections in cubic $\mathrm{km}$.

\begin{tabular}{|l|c|c|c|c|}
\hline Particulars & 1985 & 2000 & 2025 & 2050 \\
\hline Irrigation & 470 & 630 & 770 & 960 \\
\hline Domestic & 16.7 & 24.2 & 40 & 65 \\
\hline Industrial & 10 & 30 & 120 & \multirow{2}{*}{425} \\
\cline { 1 - 4 } Hydropower & 4.3 & 5.8 & 15 & \\
\hline Other uses & 39 & 6 & 105 & \\
\cline { 1 - 4 } Total: & 540 & 750 & 1050 & 1450 \\
\hline
\end{tabular}

Source: National Water Resources at a glance, Internet site: http://wrmin.nic.in/ resource.htm.

Table 2: $\quad$ Land and water resources of India.

\begin{tabular}{|l|c|}
\hline \multicolumn{1}{|c|}{ Particulars } & Quantity \\
\hline Geographical Area & 329 million ha. \\
\hline Flood Prone Area & 40 million ha. \\
\hline Ultimate Irrigation Potential & 140 million ha. \\
\hline Total Cultivable Land Area & 184 million ha. \\
\hline Net Irrigation Potential & 50 million ha. \\
\hline Natural Runoff (Surface Water and Ground Water) & 1869 cubic km. \\
\hline Estimated Utilisable Surface Water Potential & 690 cubic km. \\
\hline Groundwater Resource & 432 cubic km. \\
\hline Available Groundwater Resource for Irrigation & 361 cubic km. \\
\hline Net Utilisation Groundwater Resource for Irrigation & 325 cubic km. \\
\hline
\end{tabular}

Source: NIH, Roorkee, Water Resources of India Internet site: www.nih.ernet.in/ html_files/water.htm.

In India, there are 12 major river basins covering 25.28 Lakhs sq km catchment area and 48 medium river basins encompassing 2.485 Lakhs sq km catchment area. The most appropriate unit for water management is river subbasin or basin. A systematic study of its physiography, inflow outflow, demand patterns, environmental as well as socio-economic needs form the base for water balance in the country. Moreover, reliable quantitative information is not available on the water budget because of dearth of information on hydrological variables viz. routing, precipitation and evapotranspiration. The estimates of water resources are available based on small watershed and/or based on average 
precipitation over the entire country and measurements made at a few rain gauge stations. Stream/river flow data are confined to few rivers and often not easily assessable. Reliable hydrological models are now available which can calculate water balance of a river system provided database is realistic. Geological information system (GIS) and digital elevation model (DEM) can accurately define the drainage basin including the lakes and wet lands that can form or port watershed. Thus it is possible to use this approach to estimate the discharge at any point along the river. A successful application of using this framework has been demonstrated for the Mandovi river in Goa (Shankar, et al., [4]).

The task for water allocation for various uses in present and future scenarios and decided surplus deficit basin can be profound by developing a decision support system (DSS) (Suryawanshi, [5]). Software available for this purpose may be used to simulate the basin wise water management. Optimization techniques have been successfully used for the operation of water resources system. Most of the optimization models are based on mathematical programming technique and have been reviewed by Yeh, [6] are useful for planning purpose. The techniques can be adopted for very simple to most complex river basin systems. These tools will assist in realistic assessment of water resources, demand supply patterns, effective operation of infrastructure leading to holistic water resources management practice.

\section{Land and water linkage}

Land and water resources are environmentally interlinked. The introduction of high yield crops and energy intensive agriculture ushered the green revolution during the four decades 1950 to 1990 , leading to increased food grain production by a factor of 2.6 in this period (Nair, [7]). Now the per capita food production appears to be declining due to population explosion. Increase in food production is needed without any irreversible environmental damage. Land degradation has now become a major treat to the sustainability of world food supply. This loss arises from soil erosion, depletion of organic matter, increase in alkalinity and salinity, water logging etc. These damages are caused by poor agriculture management practices. The increase in food production has been achieved mainly by increasing crop yields, the agriculture irrigable area has expanded relatively little. The amount of water available for irrigation is also reducing and unable to meet the growing water demand for increased food requirements. The finite water resources will not be adequate unless non-conventional methods such as inter-basin transfers', and artificial recharging of ground water are adopted in near future. International Water Management Institute has developed indicators or tools for evaluating performance of irrigation systems (Prasad and Jaykumar, [8]). Food and Agriculture Organisation (FAO) [9] has also developed software for estimating crop requirements in 1995 These tools are useful in understanding and developing irrigation and optimal use of water resources.

Over exploitation of ground water resources, mostly to meet the irrigation demands has already affected the aquifer's productivity both quantitatively and qualitatively. Building of dams for surface water harvesting and ground water 
recharge help in augmentation of natural water resources. Surface water in conjugation with ground water is to utilize judicially by keeping ground water balance in equilibrium. Refilling of sub-surface reservoirs by harvesting excess monsoon runoff needs favourable geological and physiographic units. Geophysical tools specifically electrical resistivity techniques alone in ground water development and management is vital considering the effect of interlinking of rivers on land and ecological changes (Singh, [10]).

The environmental impact of modified land use pattern, as a result of intensive agriculture, based on irrigation facility, does not limit to environmental resources and ecology but are the influential factors for socio-economic growth of the region. Due to uncertainty of rain, the crop production is not dependable. This leads to poor quality of life of the people resulting into disturbed social interaction due to inadequately met want of goods and services. Development of fresh water resources is essential not only to feed the growing population of India but also to keep intact the social fabric of the community.

\section{Water resources management}

The need based water resources development should remain realistically linked to the 'need'. To cite a case, an impoundment designed for cotton crop irrigation should not be allowed to disrupt the land-water system by raising sugarcane. The environmental and ecological problems as a result of water resources development basically crop up due to over exploitation of the resources and severe compromise with social and ecological values. A participatory approach is needed in watershed development and management. A water resources management system for irrigation through community participation needs focus in near future for sustainable development (Yadava et al., [11]). From community participation perspective, building the capacity of local people means to work together to address their common interests in the local society. Technical, financial, institutional, political and social capacities need building itself for decision support on sustainable livelihood. Public cognizance will have to be registered through education, social interventions and mass movements for managing surface and ground waters in equitable and sustainable manner. If adequate attention is not devoted to the environmental issues at the inception of the project, the project has to suffer the onslaught of criticism. The mitigation plan evolved at the later date may not satisfy the total framework of environmental and socio-economic requirement. Most honoured BSL project was thoroughly studied after twenty years of it's working to evolve the solution to mitigate the serious silt problem in Suketi Khad. The silt ejected in the Suketi Khad from the dredging of balancing reservoir in Sundernagar cause environmental problems in Bahl valley.

\section{Impact of river action plans}

The evaluation of Ganga Action Plan Phase I was done in the year 1994 and Yamuna Action Plan was carried out in 2002. 


\subsection{Ganga River}

The data for the river is for 19 years (1986-2005) at 16 sites as averaged values of DO and BOD. For sake of convenience, the stretch has been divided in three zones upper (Rishikesh-Garhmukteshwar) middle (Kannauj-Varanasi) lower (Patna-Uleberia). The maximum, minimum and average values are given in the table below:

Table 3.

\begin{tabular}{|c|c|c|c|c|c|c|}
\hline & & Iax. & Min. & & Avera & \\
\hline & & & & 1986 & 1996 & 2005 \\
\hline Upper & $\mathrm{DO}$ & $\begin{array}{l}9.0 \\
\text { (Rishikesh 1993) }\end{array}$ & $\begin{array}{l}4.7 \\
\text { (Grahmukteshwar } \\
1987)\end{array}$ & 8.0 & 8.3 & 8.1 \\
\hline & BOD & $\begin{array}{l}4.9 \text { (Garhmukteshwar } \\
1998 \text { ) }\end{array}$ & $\begin{array}{l}0.5 \\
\text { (Rishikesh 2003) }\end{array}$ & 1.9 & 1.2 & 1.5 \\
\hline Middle & $\mathrm{DO}$ & $\begin{array}{l}13.0 \text { (Allahabad } \\
\text { 2002) }\end{array}$ & $\begin{array}{l}4.4 \\
\text { (Kanpur 2003) }\end{array}$ & 6.5 & 7.9 & 7.6 \\
\hline & BOD & 6.58 (Kanpur 1991) & 1.0 & 9.8 & 2.9 & 3.6 \\
\hline & & 25.0 (Kanpur 1992) & (Kannauj 1989) & & & \\
\hline & & 24.5 (Kanpur 1993) & & & & \\
\hline Lower & $\mathrm{DO}$ & 8.7 (Patna 1998) & 5.1 (Uleberia 1997) & 8.1 & 6.74 & 7.04 \\
\hline & BOD & 3.2 (Uleberia 1994) & $\begin{array}{l}0.3 \\
\text { (Rajmahal 1990) }\end{array}$ & 2.0 & 1.7 & 2.3 \\
\hline
\end{tabular}

The perusal of data reveals that upper zone meets the requirements of bathing water $(\mathrm{DO}>5.0, \mathrm{BOD}<3.0 \mathrm{mg} / \mathrm{l})$ at all time with respect to DO and BOD values. The values of 1986, 1996 and 2005 indicate that despite increase in pollution load, the quality was maintained at value prior to GAP schemes.

The critical middle zone was between Kannauj and Varanasi in 1986 with DO $<5.0$ and BOD $>3.0$ with National River Conservation Directorate NRCD programme the critical middle zone was restricted between Kannauj and Allahabad (2002-2005) thus indicating improvement in Allahabad - Varanasi stretch.

\subsection{Yamuna River}

The quality of Yamuna river water was maintained all through in Haryana state upstream of Delhi, with DO values above $5.0 \mathrm{mg} / \mathrm{l}$ and BOD values less than 3.0 $\mathrm{mg} / \mathrm{l}$. DO values were marginally lower at Kalanaur (2003) and BOD values higher at Palla (1996), just above national Capital Region of Delhi. These variations were more as exception than rule. Based on data of summer averages of 1996-2005, from the table below the following inferences can be made.

The Yamuna water at Delhi was always poor with DO values $<5.0 \mathrm{mg} / 1$ and BOD values $>3.0 \mathrm{mg} / \mathrm{l}$. 
The poor quality trend continued downstream also with values of DO fluctuating up to Majhawali. The content improved at Mathura and Agra $\mathrm{u} / \mathrm{s}$. The values were again lower $\mathrm{d} / \mathrm{s}$ Agra. However, the values improved at Baleshwar upto Auraiya. The same trend was indicated by BOD values. The maximum, minimum and average values of Yamuna WQ variations are indicated below:

Table 4 .

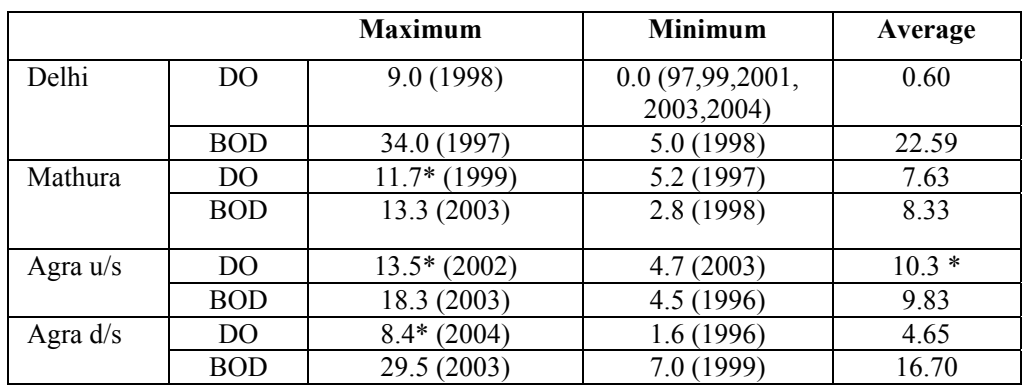

* Eutrophic status.

The critical stretch of Yamuna in 2005 extended from Delhit to udi as against Delhi to Mejhawalai and again. Agra d/s to Etawah in (1996). There was no improvement in water quality and the effect of NRCD schemes was not positive.

\section{Framework for impact mitigation}

The environmental impact and mitigation measures are, therefore, required to be very critically interwoven right from the inception of the water resources development projects. The project proposal which delineate resources, strategies, action plan for development of goods and resources, should be accompanied with the environmental impact assessment, environmental management plan, catchment area treatment plan, risk assessment and mitigation measures including dam break analysis wherever relevant, rehabilitation and resettlement plan and compensatory renewable resources generation plans.

The water conservation and mitigation of pollution in the surface water resources has been recognized by the Indian Government and promulgated water management plans in the ninth and tenth five year plans. The national river conservation plan and lake conservation plan are the major schemes to analyze and mitigate pollution in the surface sources. Interception, diversion and treatment of domestic sewage was undertaken under the Ganga Action Plan (Planning Commission 2002). Sewage treatment plants were constructed in 25 class I towns along the river Ganga to treat 870 mil of sewage. To arrest the Yamuna river pollution, 12 towns of Haryana, 8 towns of uttar Pradesh and Delhi were considered to provide waste water treatment facilities by NRCD. 
Financial aid has been given by Japan Bank for International Cooperation. Pollution abatement schemes were suggested by NEERI, in 1994 for Damodar river after having in depth water quality assessment in $350 \mathrm{~km}$ river stretch.

Development of tools to realistically assess the impact and make quantitative statement to judge the benefits of the water resources development vis-à-vis the damage tolerance level is an urgent need. This sound exercise need be based on realities, brought out by past experience and appropriate tools constantly developed in the domain of basic sciences and engineering pertaining to environmental technologies. The retention of pristine beauty of riverine system cannot be envisaged while planning the developmental project. The importance therefore, lies in devoting adequate thought to pre-decide damage tolerance level vis-à-vis the goals for achieving the goods and services from the developmental plan.

The mitigation measures to combat the adverse environmental impact of river valley developmental project must be supported with the evaluation based on well delineated and advance tools for the studies. Such tools include the sampling and analytical techniques for studies on environmental component, the conceptual framework for evaluation and appropriate modeling to predict the impact as well as results of mitigation plans.

Appropriate environmental studies with well-founded tool was also the concern of the World Commission on Dams (WCD) which was set up in 1998 by the World Bank and the World Conservation Union (WCU). It gave clear guidelines and recommendations, for decision-makers aimed at safeguarding rights, reducing the risk of conflicts and lowering overall costs, including social and environmental ones. The WCD identified six steps and prepared guidelines for decision-makers on dam construction. These steps are real needs, alternatives, preferred scenario, agreements, compliance and operations.

The dynamics of ground water and surface water interaction need be properly understood with the aid of modern techniques such as remote sensing, electrical resistivity studies and ground penetration radar. Modeling tools for rainfall and runoff, river hydrodynamics, water quality, sediment transport and water demand management for use and ecology need be adopted, improved and applied to generate scenarios which closely represent ground truth. The advance statistical techniques and opinion assessment methodology has significant role in final decision-making. The Rapid Impact Assessment Matrix (RIAM) is a tool to organize, analyze and present the results of a holistic environmental impact assessment.

\section{Conclusions}

Concerted efforts are necessary at national level in meeting the food and water security. Agriculture practices are made more environmental friendly by using modeling techniques for irrigation systems. Conservation of water in all applications - domestic, agriculture, commercial and industrial shall be given most priority to ensure sustained availability and minimum damage to the environment. Much of the water runs to waste for want of adequate schemes for 
conservation and proper storage. To meet the water demand of growing population, non-conventional methods such as inter-basin transfers, artificial recharging of ground water may have to be adopted in phased manner taking into account the environmental impacts through a holistic approach. Participatory approach is needed in watershed development and management. Public education, social interventions and mass movements are necessary in managing surface and ground water in an equitable and sustainable manner. For this purpose the worthwhile approach is to establish appropriate forum for sound basis for Environmental Impact Assessment (EIA) and Environment management Plan (EMP) for water resources development projects to delineate the adverse and beneficial impact.

\section{Acknowledgement}

The authors are grateful to Director, NEERI, Nagpur for his permission to publish the paper.

\section{References}

[1] Defluoridation, Technology Package, Published by NEERI, October 1992

[2] Andey S.P. and Nanoti M.V. "Silt Management in Run-of-the-river Hydroelectric Project ". National Conference on Pollution Prevention \& Control in India, held at VNIT, Nagpu, 2002

[3] Major river basins of the country and basin-wise ground potential of India, Internet site: wrmin.nic.in/resource/cwresourc.1.htm

[4] Shankar D., Kotamraju V. and Shetye S.R., "Towards a Framework for Quantifying Water Resources in India" Proceedings of The International Conference on Water and Environment Bhopal, India, PP: 451 - 462, 2003

[5] Suryawanshi R.K., "Decision Support System for Implementation of Integrated Water Resources Management by River Basin Organisations" pp: 197 - 204, Role of Engineers - an Indian Perspective" in Role of Engineers in All-Round Development of The Nation, The $18^{\text {th }}$ Indian Engineers Conference IEI (India) held at Lucknow, U.P. State Centre. The Institution of Engineers (India), 2003

[6] Yeh William. W-G, "Operation of Water Resources Systems", Proceedings of The International Conference on Water and Environment (WE-2003), Bhopal, India, PP 63 - 74. 2003

[7] Nair Sukumaran, M.P, "Future roadmap of the country towards the absorption of scientific and technological development in the long term: Role of Engineers - an Indian Perspective" Role of Engineers in All-round Development of The Nation, The $18^{\text {th }}$ Indian Engineers Conference IEI (India) held at Lucknow, U.P. State Centre. The Institution of Engineers (India). Page No. 407 - 417, 2003 
[8] Prasad Jyoti and Jaykumar K.V, "Irrigation system performance evaluation - A case study" Proceedings of International conference on development in hydrology at Kolkata, pp: $331-336,2002$

[9] Food and Agriculture Organisation (FAO) 1995, Food and Agriculture Software Library, Rome, Italy, Internet site: www.fao.org.

[10] Singh Hira, "Role of Geophysics in Development and Management of Ground Water Resources" Role of Engineers - an Indian Perspective" Role of Engineers in all-round Development of The Nation, The $18^{\text {th }}$ Indian Engineers Conference IEI (India) held at Lucknow, U.P. State Centre. The Institution of Engineers (India), Page No. 205 - 209, 2003

[11] Yadava, R.N., Ram, R., Padmakar C., and Peters E., "Water Resources Management Through Community Participation for Sustainable Development" pp: 256 - 263 Proceedings of The International Conference on Water and Environment, Bhopal, India, pp: 256 - 263, 2003

[12] World Commission on Dams (WCD), Guidelines and Recommendations, 1998 Internet site: www.panda.org. 